\title{
Opinión \\ de los Geógrafos
}


